\title{
A New Calibration Scale for Schiøtz, Gradle-Schiøtz and McLean Tonometers
}

The Committee on Standardization of Tonometers of the American Academy of Ophthalmology and Otolaryngology, at its meeting of September 20th, 1954, officially approved and adopted a new calibration scale for Schiøtz, Gradle-Schiøtz and McLean tonometers. The new scale, referred to hereafter as the 1954 scale, is based on extensive measurements by Friedenwald and Grant. It yields intraocular pressure estimates in approximate agreement with the Schiøtz scale of 1909, somewhat lower than the Schiøtz scale of 1924 and the Committee's scale of 1948. The data on which the new scale is based are published in the Decennial Report of the Committee on Standardization of Tonometers of the American Academy of Ophthalmology and Otolaryngology. The Committee believes that the new calibration scale is considerably more accurate than those previously in use.

It is important to realize that the clinical significance of the tonometer scale readings is in no way changed by this new and more correct estimate of what a given scale reading means in millimeters of mercury. For example, the average scale reading on normal eyes with the standard Schiøtz tonometer

The 195-í Calibration Scale for Schiøtz Tonometers.

156 A New Calibration Scale for Schiøtz, Gradle-Schiøtz ...

is generally found to lie between 5 and 6 scale units with the $5.5 \mathrm{gm}$. load. This is still the average normal reading, but the new calibration scale indicates that this average normal reading corresponds to 15 to $18 \mathrm{~mm}$. $\mathrm{Hg}$, that is to values considerably lower than was previously thought.

Similarly, a scale reading of 3.0 or less with the 5.5 weight has previously been regarded as suspicious of glaucoma and this remains true. This concept has previously been expressed in terms of "the upper limit of normal". More precisely it may be stated that scale readings of 3.0 or less with the 5.5 weight are rarely obtained in normal eyes. The new calibration scale translates this statement into: "Intraocular pressures higher than $25 \mathrm{~mm}$. Hg on the new scale are rarely encountered in normal eyes.”

The chart shown below refers to the standard Schiøtz instrument with concave plunger base. Charts for the Gradle-Schiøtz and McLean tonometers may be obtained from the respective manufacturers.

The Committee herewith officially recommends the adoption of the 1954 scale.

Buchbesprechungen - Book Reviews - Livres Nouveaux

Valdemar Hertz: Choroidal Detachment with Notts on Scleral Depression and Pignientcd Streaks in the Hetina. (Acta Ophthalmologica, Suppl. 41). E. Munksgaard, Copenhagen 1954. 256 pages. Das vorliegende Buch bringt eine wohl lückenlose Zusammenstellung derL· iteratur über die im Titel genannten Augenerkrankungen. Die einzelnen Ar-beiten werden sehr ausführlieh referiert, so daß für spätere Bearbeiterdie Einsicht der Originalarbeiten erspart bleibt. Im ersten Teil 
werden dieAderhautabhebungen im Anschluß an Contusionen des Augapfels besprochen, im zweiten Teil die nicht-traumatischen. Über eigene Erfahrungen wird nichtberichtet, dagegen werden die Beziehuiigen zur Netzhautabhebung, die Art deranatomischen Verínderungen, die Aetiologie der Erkrankungen u. a. verglei-chend erörtert. A. Bruckner.

H. Frenzel: Spontan- und Provokations-Nystagmus als Krankheitssymptom.

Springer-Verlag, Berlin/Göttingen/Heidelberg 1955. VII + 72 Seiten, 60 Abb. DM 16.80.

A. Auf Grund einer eigenen dreißigjährigen Erfahrung bei der Untersuchung des Nystagmus schildert der Autor seine Methode

die sich auf eine verfeinerte Art der einfachen Beobachtung des Nystagmus bei den

verschiedenen Stellun-gen der Augen und des Kopfes bezieht. Daraus allein kann man schon sehr viel entnehmen

ohne daß man die übrigen Untersuchungsverfahren (kalori-scher Reiz

Drehnystagmus) heranzieht. Zur Feststellung

ob schon ein Spontan- 